\title{
Disparities in Per Unit Fertilizer Consumption in Respective of Gross Cropped Area, Gross Irrigated Area and Total Rainfed Area in Telangana State
}

\author{
Srikanth Bairi*, V.V. Narendranath and M.H.V. Bhave \\ Agricultural Statistics, ICAR-IASRI (IARI), Pusa Campus, Library Avenue \\ New Delhi-110012, India \\ *Corresponding author
}

\begin{abstract}
Keywords
Fertilizer

Consumption,

Gross Irrigated

Area

Article Info

Accepted:

10 July 2019

Available Online:

10 August 2019 area of irrigation facilities adopted by the farmers of particular locality. The results revealed that, the demand for fertilizers specially for major nutrients (NPK) is vast, however, in this study it was interesting to note that, potassic fertilizers, the adjusted R2 (2) for cubic model was identified as the best fitting model for Potash fertilizer demand in the Telangana region as this function had higher $2(0.953)$ with relatively low residual mean square. The study results also revealed that, The compound growth rate of per unit consumption of $\mathrm{N}, \mathrm{P}, \mathrm{K}$ and Total NPK fertilizers in Telangana region is $6.56 \%, 8.32 \%, 11.94 \%$ and $7.32 \%$ for the Gross Cropped Area, the Gross Irrigated Area and the Total Rainfed Area respectively. Hence the study suggest that, to improve the fertilizer use efficiency farmers should opt for biological fertilizers which can reduce the pollution for soil environment and helps in obtaining farm yields on sustainability basis in long-run. In addition, government should frame policies to attract biological fertilizers in order to get ride of burden of subsidy.
\end{abstract}

\section{A B S T R A C T}

The present paper makes an attempt to investigate the fertilizer consumption in Telangana region covering 10 districts in the study area conducted during 201213. The results revealed that, the consumption rate was varying according to the

\section{Introduction}

Fertiliser is a major input for any crop in Indian Agriculture. Nitrogen, Phosphatic and Potassic fertilizers are found to be major consuming fertilizers in crop production.

In the present context an effort was made to study the fertilizer consumption patterns and to study the per unit consumption with regard to gross cropped area, gross irrigated area and total rainfed area in Telangana region.

The Data for The gross cropped area, gross irrigated area, total Rainfed area and the Fertiliser consumption for N, P, K and Total for the period 1967-68 to 2009-10 (42 years) was collected from Seasonal and Crop reports of the Directorate of Economics and Statistics, Government of Andhra Pradesh. 
Telangana is situated in the central stretch of the eastern seaboard of the Indian Peninsula (Deccan Plateau). Of the three regions of the state of Andhra Pradesh, Telangana has the largest area, with 114,800 square kilometers. The Deccan plateau is drained by two major rivers, the Godavari and the Krishna. $69 \%$ of the Krishna River and $79 \%$ of the Godavari River catchment area is in Telangana region. Telangana is also drained by other minor rivers such as Manair, Bhima, Dindi, Kinnerasani, Manjeera, Munneru, Moosi, Penganga, Praanahita and Peddavagu and Taliperu.

The gross cropped area, gross irrigated area and total Rainfed area in Telangana region is $5.02 \mathrm{mha}, 1.07 \mathrm{mha}$ and $3.95 \mathrm{mha}$ respectively during 1967-68 but decreased to 4.93mha in gross cropped area and to $3.32 \mathrm{mha}$ in total rainfed area. There is an increase in gross irrigated area to $1.60 \mathrm{mh}$.

Nitrogen, Phosphatic and Potassic fertilizers are found to be major consuming fertilizers in crop production. Among these fertilizers, Nitrogen is consumed relatively more than the other two fertilizers in all the years of study period. Averages of Areas and Fertilizer consumption for Telangana region are presented in the Table 1.

The Average Gross Cropped Area, the Gross Irrigated Area and the Total Rainfed Area is 4933432.88 ha, 3323632.79 ha and 1609800 ha respectively. The Average percentage of Gross Irrigated Area out of Total Cropped Area is $32.74 \%$ and the remaining area of $67.26 \%$ is the Total Rainfed Area in the Telangana region.

The percentage of Gross Irrigated Area in $1967-68$ is $21.32 \%$ and it has been increased to $43.51 \%$ in $2009-10$ in this region. The trend in the Gross Irrigated Area has been presented. The average per unit consumption of $\mathrm{N}, \mathrm{P}, \mathrm{K}$ and total NPK fertilizers are 282, 112, 37 and $431 \mathrm{~kg} / \mathrm{ha}$ respectively for GIA in the Telangana region.

In Telangana region the percentage of the Total Rainfed Area in 1967-68 is $78.68 \%$ and it has decreased to $56.49 \%$ in $2009-10$. The average per unit consumption of $\mathrm{N}, \mathrm{P}, \mathrm{K}$ and total NPK fertilisers are 76, 30, 10, $117 \mathrm{~kg} / \mathrm{ha}$ respectively under the Total Rainfed Area.

The Gross Cropped Area in Telangana region in 1967-68 is 5025703 ha and it has decreased to 4898900 ha in $2009-10$. The overall average per unit consumption of fertilizers is relatively less when compared to the Gross Irrigated Area and the Total Rainfed Area. The average per unit consumption of $\mathrm{N}, \mathrm{P}, \mathrm{K}$ and Total NPK fertilizers are 60, 24, 8 and $92 \mathrm{~kg} / \mathrm{ha}$ respectively in the Gross Cropped Area in Telangana region.

Growth models are useful in drawing inferences like the exact relationship between time and growth. The rate of growth at each point of time, the turning points in the growth. Waghmare and Sorgekar (1991) studied district wise trends in fertilizer consumption in Maharashtra using compound growth rate and the districts were classified into different class intervals according to growth rates they have achieved during the 14 years period from 1972-73 to 1986-87. Leela (1985) examined the growth in per hectare consumption of fertilizers in different districts of Andhra Pradesh during the period of two decades (1960-1980).

In the context of agricultural time series data recorded over a period of years, the Compound Growth Rate (CGR) is derived as an exponential equation,

$Y=a b^{t}$

Where, 
$\mathrm{Y}=$ Observed Time series data

$\mathrm{t}=$ Time (years) and

$(\mathrm{a}, \mathrm{b})=$ Parameters

The compound growth rate (CGR) is

$C G R=(r)=(b-1) \times 100$

If $\mathrm{N}$ years of data are available, the CGR is estimated by fitting the exponential relation (1).

It is in during this fitting relation, certain statistical inferences are highlighted.

These are, for example, computing $r^{2}$ (coefficient of determination) and testing the significance of the parameter $b$ which is estimated as ' $\log b$ ', in linear form.

The trend equations were fitted by using different trend models. Trend models are nothing but the models that describe the behavior of a variable over time. The trend models taken under consideration here are as follows:

\section{Linear function}

The mathematical equation is given by

$Y_{t}=a+b t$

\section{Quadratic function}

Quadratic or second degree curve described by an equation of the type is given as:

$Y_{t}=a+b t+c t^{2}$

\section{Cubic function}

Cubic function or third degree curve described by an equation of the type.

$Y_{t}=a+b t+c t^{2}+d t^{3}$

\section{Logarithmic function}

The mathematical equation is given by

$Y_{t}=a+b \ln (t)$

\section{Inverse function}

Inverse fit is given by the equation.

$Y_{t}=a+\frac{b}{t}$

\section{Exponential Model}

Exponential function is given as

$Y_{t}=a b^{t}$

$Y_{t}$ is the dependent variable, i.e. the observed time series data

$t$ is the independent variable, time in years

$\mathrm{a}$ and $\mathrm{b}$ are the constants.

The constants 'a' and 'b' are estimated by the Ordinary Least Squares approach.

In the present study, the model with least residual mean square (RMS) and significant Adj R2 considered to be best fitted model.

$$
R^{2}=\frac{\text { EXPLAINEDVARIATION }}{\text { TOTALVARIATION }}=\frac{\sum_{\overline{\mathrm{i}}=1}^{\mathrm{n}}\left(\widehat{\mathbf{Y}}_{\overline{\mathrm{i}}}-\mathbf{Y}\right)^{2}}{\sum_{\mathrm{i}=1}^{\mathrm{n}}\left(\mathbf{Y}_{\mathrm{i}}-\overline{\mathbf{Y}}\right)^{2}}
$$

$\operatorname{Adj} R^{2}=\left(\overline{R^{2}}\right)=R^{2}-\left[\frac{K-1}{N-K}\right]\left(1-R^{2}\right)$

Where,

$\mathrm{K}$ is the number of constants in the equation.

The compound growth rates of the Gross Cropped Area, the Gross Irrigated Area and the Total Rainfed Area of Telangana region are presented in Table 1. 
Table.1 Growth rates for different areas in Telangana (1967-68 to 2009-10)

\begin{tabular}{|l|r|r|r|}
\hline \multicolumn{1}{|c|}{ Character } & \multicolumn{1}{c|}{ GIA } & \multicolumn{1}{c|}{ TRA } & \multicolumn{1}{c|}{ GCA } \\
\hline Mean (Hectares) & \multicolumn{1}{c|}{6099800} & 3323632.79 & 4933432.88 \\
\hline S.D (Hectares) & 469883.31 & 559336.07 & 334574.82 \\
\hline C.V (\%) & 29.19 & 16.83 & 6.78 \\
\hline CGR (\%) & 1.61 & -0.83 & -0.06 \\
\hline
\end{tabular}

Table.2 Growth rates for per unit Consumption of Fertilizers in Telangana (1967-68 to 2009-10)

\begin{tabular}{|c|c|c|c|c|}
\hline Area & Fertilizer & SD (Kgs) & CV (\%) & CGR (\%) \\
\hline GIA & Nitrogen & 197 & 70.07 & 6.56 \\
\hline & Phosphate & 84 & 75.32 & 8.32 \\
\hline & Potash & 44 & 118.03 & 11.94 \\
\hline & Total NPK & 320 & 74.21 & 7.32 \\
\hline & Nitrogen & 53 & 70.07 & 6.56 \\
\hline TRA & Phosphate & 23 & 75.32 & 8.32 \\
\hline & Potash & 12 & 118.03 & 11.94 \\
\hline & Total NPK & 87 & 74.21 & 7.32 \\
\hline & Nitrogen & 42 & 70.07 & 6.56 \\
\hline & Phosphate & 18 & 75.32 & 8.32 \\
\hline & Potash & 9 & 118.03 & 11.94 \\
\hline & Total NPK & 68 & 74.21 & 7.32 \\
\hline
\end{tabular}

Table.3 Trend models for the per unit consumption of N, P, K and Total NPK for the three areas in Telangana region

\begin{tabular}{|c|c|c|c|c|c|c|c|}
\hline \multirow[t]{7}{*}{$\mathbf{N}$} & & & LINEAR & LOGARTHMIC & INVERSE & QUADRATIC & CUBIC \\
\hline & \multirow[t]{2}{*}{ GCA } & $\operatorname{Adj} R^{2}$ & 0.926 & 0.672 & 0.217 & 0.939 & $0.941 * *$ \\
\hline & & RMS & 131.8 & 581.591 & 1386.297 & 107.96 & 104.574 \\
\hline & \multirow[t]{2}{*}{ GIA } & $\operatorname{Adj} R^{2}$ & 0.926 & 0.672 & 0.217 & 0.939 & $0.941 * *$ \\
\hline & & RMS & 2900.549 & 12800.085 & 30511.023 & 2375.84 & 2301.31 \\
\hline & \multirow[t]{2}{*}{ TRA } & Adj $R^{2}$ & 0.926 & 0.672 & 0.217 & 0.939 & $0.941^{* *}$ \\
\hline & & RMS & 212.874 & 939.398 & 2239.145 & 174.35 & 168.89 \\
\hline \multirow[t]{6}{*}{$\mathbf{P}$} & \multirow[t]{2}{*}{ GCA } & $\operatorname{Adj} R^{2}$ & 0.901 & 0.651 & 0.212 & $0.919 * *$ & 0.917 \\
\hline & & RMS & 31.953 & 112.87 & 255.118 & 26.365 & 26.999 \\
\hline & \multirow[t]{2}{*}{ GIA } & $\operatorname{Adj} R^{2}$ & 0.901 & 0.651 & 0.212 & $0.919 * *$ & 0.917 \\
\hline & & RMS & 703.454 & 2484.427 & 5615.052 & 580.43 & 594.383 \\
\hline & \multirow[t]{2}{*}{ TRA } & $\operatorname{Adj} R^{2}$ & 0.901 & 0.651 & 0.212 & $0.919 * *$ & 0.917 \\
\hline & & RMS & 51.637 & 182.33 & 412.058 & 42.61 & 43.634 \\
\hline \multirow[t]{6}{*}{$\mathbf{K}$} & \multirow[t]{2}{*}{ GCA } & $\operatorname{Adj} R^{2}$ & 0.665 & 0.378 & 0.092 & 0.874 & $0.953^{* *}$ \\
\hline & & RMS & 28.901 & 53.596 & 78.324 & 10.83 & 4.058 \\
\hline & \multirow[t]{2}{*}{ GIA } & $\operatorname{Adj} R^{2}$ & 0.665 & 0.378 & 0.092 & 0.874 & $0.953^{* * *}$ \\
\hline & & RMS & 636.118 & 1179.622 & 1723.919 & 238.395 & 89.274 \\
\hline & \multirow[t]{2}{*}{ TRA } & $\operatorname{Adj} R^{2}$ & 0.665 & 0.378 & 0.092 & 0.874 & 0.953 ** \\
\hline & & RMS & 46.683 & 86.568 & 126.51 & 17.495 & 6.556 \\
\hline \multirow{6}{*}{$\begin{array}{c}\text { TOTAL } \\
\text { NPK }\end{array}$} & \multirow[t]{2}{*}{ GCA } & $\operatorname{Adj} R^{2}$ & 0.915 & 0.646 & 0.204 & $0.944 * *$ & 0.943 \\
\hline & & RMS & 394.724 & 1642.792 & 3693.059 & 258.879 & 265.516 \\
\hline & \multirow[t]{2}{*}{ GIA } & $\operatorname{Adj} R^{2}$ & 0.915 & 0.646 & 0.204 & $0.944 * *$ & 0.943 \\
\hline & & RMS & 8688.191 & 36158.109 & 81283.907 & 5698.146 & 5844.23 \\
\hline & \multirow[t]{2}{*}{ TRA } & Adj $R^{2}$ & 0.915 & 0.646 & 0.204 & $0.944 * *$ & 0.943 \\
\hline & & RMS & 637.591 & 2653.521 & 5965.179 & 418.169 & 428.889 \\
\hline
\end{tabular}

$(* *=$ significantly differed at $5 \%$ level of significance $)$ 
In Telangana region, the Gross Cropped Area, the Gross Irrigated Area and the Total Rainfed Area had a CGR which were -0.06, 1.61 and -0.83 respectively. In this the Gross Irrigated Area has shown a positive trend indicating that the Gross Irrigated Area has been increased over the years during the study period. The Gross Cropped Area and the Total Rainfed Areas have shown negative trend indicating that those areas were decreased over the years.

The average area under the Rainfed conditions was more than that under the irrigated conditions in Telangana region. The coefficient of variation for the Gross Cropped Area, the Gross Irrigated Area and the Total Rainfed Area are 6.78\%, 29.19\% and 16.83\% respectively. The coefficient of variation for the Gross Irrigated Area was higher than that of the Gross Cropped Area and the Total Rainfed Area in Telangana region. The results thus revealed that more agricultural area was being brought under irrigation with time in this region.

The compound growth rate of per unit consumption of $\mathrm{N}, \mathrm{P}, \mathrm{K}$ and Total NPK fertilizers in Telangana region is $6.56 \%$, $8.32 \%, 11.94 \%$ and $7.32 \%$ for the Gross Cropped Area, the Gross Irrigated Area and the Total Rainfed Area respectively are presented in Table 2.

The highest compound growth rate of $11.94 \%$ is recorded for Potassic fertilizer consumption. That is the year by year, the per unit consumption of Potassic fertilizers is increased by $11.94 \%$ during $1967-68$ to 2009 10 in Telangana region.

For Telangana region, the per unit consumption of Nitrogenous fertilizers the adjusted $R^{2}\left(\overline{\mathbf{R}}^{2}\right)$ values of the models ranged from 0.217 (inverse) to 0.941 (cubic) and are same for the Gross Cropped Area, the Gross
Irrigated Area and the Total Rainfed Area. Among these models the cubic model was identified as the best fitting model for nitrogen demand in Telangana region as this function had higher $\overline{\mathbf{R}}^{2}$ (0.941) with relatively low residual mean square.

The per unit consumption of Phosphatic fertilizers in the Telangana region, the adjusted $R^{2}\left(\overline{\mathbf{R}}^{2}\right)$ values of the models ranged from 0.212 (inverse) to 0.917 (quadratic) and observed same for the Gross Cropped Area, the Gross Irrigated Area and the Total Rainfed Area. Among these models the quadratic model was identified as the best fitting model for phosphate demand in the Telangana region as this function had higher $\overline{\mathbf{R}}^{2}$ (0.917) with relatively low residual mean square.

For Potassic Fertilizers, the adjusted $R^{2}\left(\overline{\mathbf{R}}^{2}\right)$ values of the models ranged from 0.092 (inverse) to 0.953 (cubic) and are same for the Gross Cropped Area, the Gross Irrigated Area and the Total Rainfed Area. Among these models the cubic model was identified as the best fitting model for Potash fertilizer demand in the Telangana region as this function had higher $\overline{\mathbf{R}}^{2}$ (0.953) with relatively low residual mean square.

In the per unit consumption of Total NPK fertilizers in the Telangana region, the adjusted $R^{2}\left(\overline{\mathbf{R}}^{2}\right)$ values of the models ranged from 0.204 (inverse) to 0.944 (quadratic) and are as same for the Gross Cropped Area, the Gross Irrigated Area and the Total Rainfed Area.

Among these models the quadratic model was identified as the best fitting model for Total NPK demand in the Telangana region as this function had higher $\overline{\mathbf{R}}^{2}$ (0.944) with relatively low residual mean square are presented in Table 3. 
It can be concluded that the Fertilizer consumption is related with the area under irrigation.

\section{References}

Chanchal, P. 2010. Study of Fertilizer consumption pattern in districts of northern telangana region of Andhra Pradesh, M. Sc. thesis, College of Agriculture, Rajendranagar, Acharya N G Ranga Agricultural University.

Leela P 1985 Fertiliser consumption in
Andhra Pradesh. Agriculture Situation in India. 60(8): 677-682.

Mathur B K and Henry A 2005 Compound growth rate of area, production and productivity of pulses (moth bean, cowpea, and mung bean) in arid districts of Rajasthan. Journal of Arid Legumes. 2(1): 50-53.

Waghmare P R and Sorgekar K R 1991 District wise trends in fertilizer consumption and use per hectare in Maharashtra state. Fertiliser Marketing News. 22(7): 2-7.

\section{How to cite this article:}

Srikanth Bairi, V.V. Narendranath and Bhave, M.H.V. 2019. Disparities in Per Unit Fertilizer Consumption in Respective of Gross Cropped Area, Gross Irrigated Area and Total Rainfed Area in Telangana State. Int.J.Curr.Microbiol.App.Sci. 8(08): 937-942. doi: https://doi.org/10.20546/ijcmas.2019.808.109 